\title{
Modelling Aboveground Biomass of Miombo Woodlands in Niassa Special Reserve, Northern Mozambique
}

\author{
Orlando A. Macave ${ }^{1}$, Natasha S. Ribeiro ${ }^{2,3, * \mathbb{D}}$, Ana I. Ribeiro ${ }^{4}{ }^{(\mathbb{D}}$, Aniceto Chaúque ${ }^{2}$, Romana Bandeira ${ }^{2}$, \\ Cristina Branquinho ${ }^{5}\left(\mathbb{D}\right.$ and Robert Washington-Allen ${ }^{6}(\mathbb{B})$
}

1 MRV Unit from FNDS (National Fund for Sustainable Development), Ministry of Agriculture and Rural Development, Maputo City P.O. Box n 1406 , Mozambique; nandomacave@gmail.com

2 Faculty of Agronomy and Forest Engineering, Eduardo Mondlane University, Maputo 3453, Mozambique; achauque2012@gmail.com (A.C.); romana.bandeira467@gmail.com (R.B.)

3 Department of Environmental Sciences, University of Virginia, Charlottesville, VA 22903, USA

4 Forest Research Center (CEF) and Lab Terra, School of Agriculture, University of Lisbon, Tapada da Ajuda, 1349-017 Lisbon, Portugal; aribeiro@isa.ulisboa.pt

5 Centre for Ecology and Environmental Changes (CE3C), Faculty of Sciences, University of Lisbon, 1349-017 Lisbon, Portugal; cmbranquinho@fc.ul.pt

6 Department of Agriculture, Veterinary \& Rangeland Sciences, University of Nevada, Reno, NV 89557, USA; rwashingtonallen@unr.edu

* Correspondence: nsr8s@virginia.edu; Tel.: +258-826341259

check for updates

Citation: Macave, O.A.; Ribeiro, N.S.; Ribeiro, A.I.; Chaúque, A.; Bandeira,

R.; Branquinho, C.;

Washington-Allen, R. Modelling Aboveground Biomass of Miombo Woodlands in Niassa Special Reserve, Northern Mozambique. Forests 2022, 13, 311. https://doi.org/10.3390/ f13020311

Academic Editors: Francesco Pirotti, L. Monika Moskal, H.

Jaime Hernández Palma, Gaia Vaglio Laurin and Erico Kutchartt

Received: 15 December 2021 Accepted: 11 February 2022 Published: 14 February 2022

Publisher's Note: MDPI stays neutral with regard to jurisdictional claims in published maps and institutional affiliations.

Copyright: (C) 2022 by the authors. Licensee MDPI, Basel, Switzerland. This article is an open access article distributed under the terms and conditions of the Creative Commons Attribution (CC BY) license (https:// creativecommons.org/licenses/by/ $4.0 /)$.

\begin{abstract}
Aboveground biomass (AGB) estimation plays a crucial role in forest management and carbon emission reporting, especially for developing countries wishing to address REDD+ projects. Both passive and active remote-sensing technologies can provide spatially explicit information of AGB by using a limited number of field samples, thus reducing the substantial budgetary cost of field inventories. The aim of the current study was to estimate AGB in the Niassa Special Reserve (NSR) using fusion of optical (Landsat 8/OLI and Sentinel 2A/MSI) and radar (Sentinel 1B and ALOS/PALSAR-2) data. The performance of multiple linear regression models to relate ground biomass with different combinations of sensor data was assessed using root-mean-square error (RMSE), and the Akaike and Bayesian information criteria (AIC and BIC). The mean AGB and carbon stock (CS) estimated from field data were estimated at $56 \mathrm{Mg} \mathrm{ha}^{-1}$ (ranging from 11 to $95 \mathrm{Mg} \mathrm{ha}^{-1}$ ) and $28 \mathrm{MgC} \mathrm{ha}^{-1}$, respectively. The best model estimated AGB at $63 \pm 20.3 \mathrm{Mg} \mathrm{ha}^{-1}$ for NSR, ranging from 0.6 to $200 \mathrm{Mg} \mathrm{ha}^{-1}\left(r^{2}=87.5 \%\right.$, AIC $=123$, and BIC = 51.93). We obtained an RMSE \% of 20.46 of the mean field estimate of $56 \mathrm{Mg} \mathrm{ha}^{-1}$. The estimation of AGB in this study was within the range that was reported in the existing literature for the miombo woodlands. The fusion of vegetation indices derived from Landsat/OLI and Sentinel 2A/MSI, and backscatter from ALOS/PALSAR-2 is a good predictor of AGB.
\end{abstract}

Keywords: remote sensing; allometric models; biomass; REDD+

\section{Introduction}

Forest ecosystems have become the focus of international efforts to mitigate the effects of climate change due to their role in carbon sequestration, combating desertification, maintaining biodiversity and protecting soil and water resources [1]. In this context, the United Nations Framework Convention on Climate Change (UNFCCC) challenged countries to commit themselves to update and elaborate periodic national inventories of biomass and carbon sequestered by forests [2,3].

The miombo woodlands are the largest dryland forest ecosystem in Sub-Saharan Africa, with an area that extends to approximately 1.9 million $\mathrm{km}^{2}$ distributed across seven countries (Mozambique, Malawi, Tanzania, Zimbabwe, Zambia, Angola, and Democratic Republic of Congo [4,5]). These countries are among the poorest globally, and the high 
dependence of the human population on these woodlands imposes many challenges in conserving this important ecosystem [6-8]. In fact, between 2005 and 2012, the miombo woodlands were lost at a rate of about $0.46 \%$ per year in southern Africa, resulting in a myriad of consequences including biomass loss [9]. Despite this loss, the miombo woodlands still play an important role in providing key goods and services, including biodiversity conservation and mitigation through carbon sequestration. Therefore, miombo countries could voluntarily engage in REDD+ programs (reducing emissions from deforestation and forest degradation, the role of conservation, sustainable management of forest and enhancement of forest carbon stocks in developing countries). This financing mechanism was globally adopted to compensate developing countries for actions taken to reduce carbon dioxide from atmosphere [10,11].

About 34 million hectares ( $42 \%$ of the territory) of Mozambique is forested, consisting mostly of broadleaved deciduous and semideciduous dry forest or woodlands that include the extensive miombo woodlands [12]. However, the rates of deforestation $(\sim 0.8 \%$ year $^{-1}$ ) and forest degradation are high $[12,13]$. Thus, a REDD+ partnership has potential as a financing mechanism to change this situation [9]. A prerequisite for REDD+ is the monitoring, reporting, and verification (MRV) of baseline carbon stocks [14-16]. A robust MRV system that complies with the Intergovernmental Panel on Climate Change (IPCC) Good Practice Guidelines [17] involves estimates of carbon stock and stock changes over time $[15,18]$. However, the challenge in implementing a REDD+ program is the lack of local data and national parameters [19]. Field-based sample surveys such as National Forest Inventories are traditionally used to provide regional and national estimates of aboveground biomass (AGB), which can be converted into carbon stock (CS) using the default conversion factor provided by IPCC; carbon is usually $50 \%$ of dried plant biomass $[1,20]$.

Aboveground biomass studies in Mozambique have increased substantially in the past 10 years, especially on developing biomass models using field data [15,21-27]. Although field-based studies are valuable for REDD+ purposes since they represent a primary source of AGB data, estimates are often not sufficient due to the inaccessibility of field sample sites, which may make them costly and sometimes unfeasible [18,28].

In the last few decades, remote-sensing (RS) technologies have emerged as a primary tool that alleviates some of the field data sampling limitations by increasing the precision of inventory estimates, and reducing the costs of forest resource inventory and monitoring at landscape scales $[18,28,29]$. The majority of RS studies use optical (e.g., Landsat, Sentinel 2A, Lidar), synthetic aperture radar (SAR, e.g., Sentinel 1) RS data, or a fusion of datasets [16,22,23,30-33]. Optical images are dependent on atmospheric conditions at the time of data acquisition [34]. However, SAR are active sensors that emit radiation at wavelengths that are less susceptible to atmospheric backscattering and thus have high transmissivity through clouds [35]. Both types of RS data are correlated to AGB, and can thus be used to adjust a specific model that represents the relationship with field data [31]. The model is then applied to predict AGB where field plots are lacking, thereby producing landscape estimations [29]. The main caveat in using RS data (both optical and SAR) is their saturation at high AGB (greater than $80 \mathrm{Mg} \mathrm{ha}^{-1}[22,35]$ ). In this regard, longer-wavelength SAR data (e.g., Advance Land Observing Satellite/Phased Array Type L-band Synthetic Aperture Radar 2 (ALOS/PALSAR 2), L-band $\sim 23.7 \mathrm{~cm}$ ) improve the models, especially in tropical forests [36]. In Mozambique, the application of RS techniques to estimate AGB is still in the early stages $[22,36,37]$. However, given its potential to estimate large-scale AGB, RS data play a fundamental role in the REDD+ mechanism; thus, it is important to further develop this tool and apply it to key areas in the country [18].

The Niassa Special Reserve (NSR) is located in northern Mozambique and is one of the least explored places in Africa [38]. This area represents 30\% of the total protected area in the country and is one of the last remnants of the miombo woodlands in Sub-Saharan Africa [39]. In addition, the reserve has high biological diversity that includes more than 800 species of plants, half of them endemic, several mammalian species, and over 400 bird 
species [40]. Thus, the reserve may contribute to global carbon storage and sequestration, and biodiversity conservation [15,38].

Despite their global importance, the miombo woodlands in NSR are under threat due to accelerated human population growth and consequent expansion of agricultural areas, the uncontrolled use of fire for clearing agricultural fields, poaching, honey extraction, and fish drying [41]. Therefore, understanding the exact role of the reserve in biodiversity conservation and management of the miombo woodlands, among others, is crucial to maintain this ecosystem. REDD+ could be a financing mechanism for conservation action in NSR that may assist in improving the income of local communities while promoting biodiversity conservation [9]. This study is a way of providing local AGB estimations at a landscape spatial scale. This updated information is important in developing REDD+ initiatives and supporting conservation action in this key biodiversity hotspot, the Niassa Special Reserve.

The objectives of this study are twofold: (1) estimating AGB from field data, and (2) developing a model and mapping the AGB using passive and active satellite RS technology that is calibrated and validated using ground data.

\section{Materials and Methods}

\subsection{Study Site Description}

This study was conducted in the Niassa Special Reserve (NSR), which is located in northernmost Mozambique $\left(12^{\circ} 38^{\prime} 48.67^{\prime \prime} \mathrm{S} / 11^{\circ} 27^{\prime} 05.83^{\prime \prime} \mathrm{S}\right.$ and $36^{\circ} 25^{\prime} 21.16^{\prime \prime} \mathrm{E} / 38^{\circ} 30^{\prime} 23.74^{\prime \prime}$ E) bordering Tanzania, and extending across $42,300 \mathrm{~km}^{2}$ in the provinces of Cabo Delgado and Niassa $[15,22,42]$ (Figure 1). The climate of the NSR is tropical subhumid, with a mean annual precipitation of $900 \mathrm{~mm}$ increasing from the east $(800 \mathrm{~mm})$ to the west $(1200 \mathrm{~mm})$, and a mean annual temperature of $25^{\circ} \mathrm{C}$ that ranges between 20 and $26^{\circ} \mathrm{C}$ during the dry season (May to October) [38,42]. NSR has a gently undulating landscape on a plateau with elevations ranging between 300 and $600 \mathrm{~m}$ above sea level (masl) [15]. There are two major peaks in the reserve, Mount Jao in the west (at 1200 masl) and Mount Mecula in the east (at 2000 masl), which are biodiversity hotspots in the area [43]. Drainage is dominated by the Rovuma and Lugenda Rivers, which are large sandy rivers with strong perennial flows [44].

Deciduous miombo woodlands cover more than $70 \%$ of the total area [45] and are dominated by a few tree species, namely, Julbernardia globiflora, Brachystegia spp., Diplorynchus condilocarpon, and Pseudolachnostylis maprouneifolia, and a dense grass layer [15,22]. Despite having lost $0.9 \%$ of its woodland cover in 2001-2014 [38], NSR's diverse ecosystems are still intact and have the potential to sustain key wildlife populations, including the largest populations of elephants in Mozambique ( 3-4000), lions (1000-1200), leopards, wild dogs (400-450), sables, kudus, wildebeests, buffalos, zebras, and more than 400 bird species [46-48]. The woodland ecology is largely driven by the rainfall gradient across NSR, and a complex interaction between anthropogenic fire and herbivory by elephants [15,22,40-42].

Human population inside the reserve is estimated to have increased from ca. 45,000 inhabitants in 2009 [48] to ca. 60,000 in 2017 [49]. As is understood anecdotally, fire is an inexpensive and readily accessible management tool for most human activities, including subsistence hunting, pedestrian trade travel to and from Tanzania, honey collection, and slash-and-burn agriculture (Tilley and Abacar, unpublished data; Chande, pers.com., 07/2015). Between 2000 and 2012, the average fire frequency for the entire area was estimated at 3.29 years, but annual burning intervals took place in $45 \%$ of NSR [41]. 

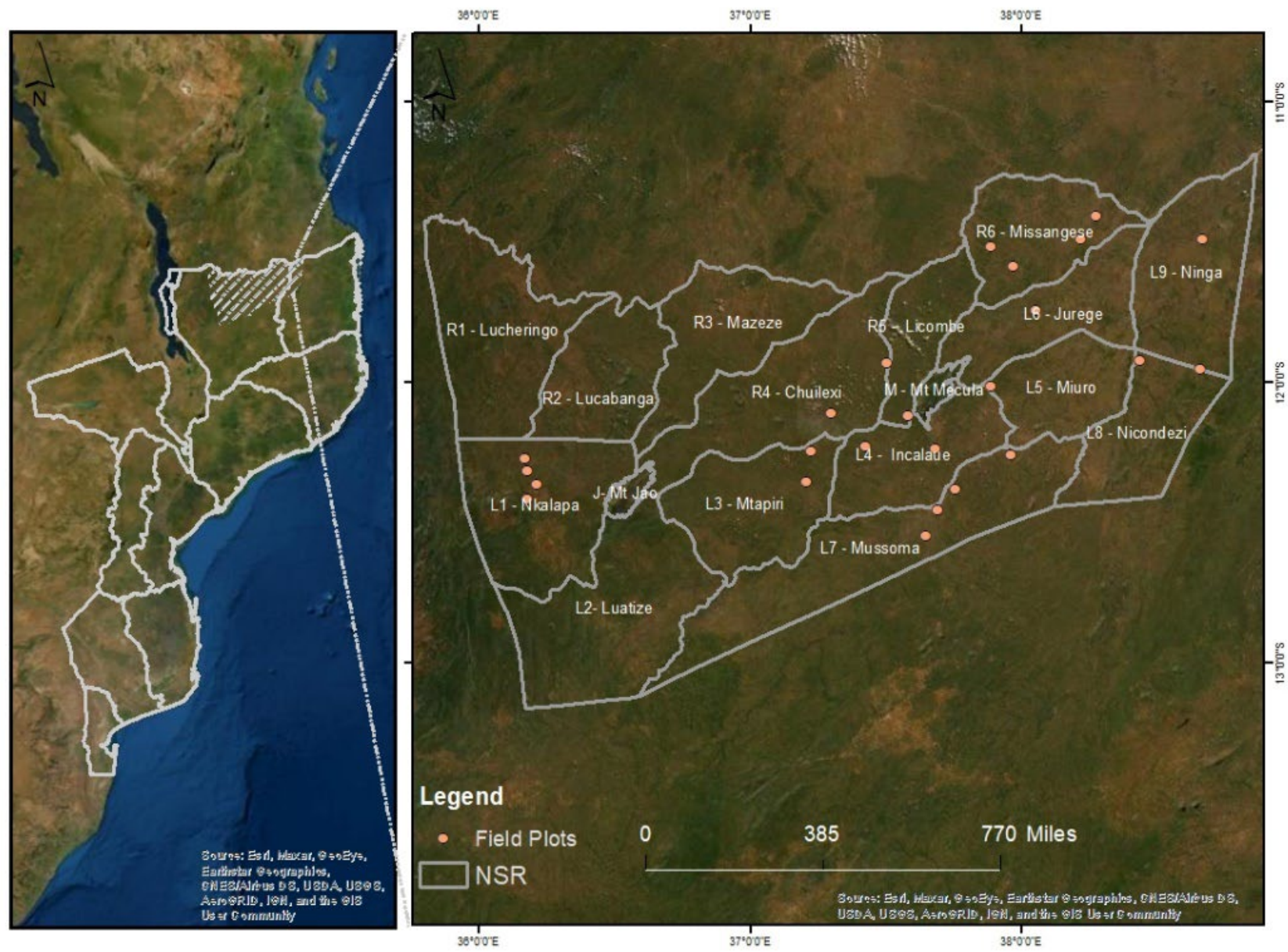

Figure 1. Location of Mozambique on the southeastern coast of Africa (left). Location of study area (Niassa Special Reserve) in northern Mozambique (left and right). Brown dots on the right represent sampling plots of 1 hectare.

\subsection{Data Acquisition}

\subsubsection{Field Data}

During 2017, 24 permanent 1 ha $(100 \times 100 \mathrm{~m})$ north-to-south orientation [50] plots were established across NSR using a stratified random sampling design. The tree canopy cover map of NSR was freely acquired from the Global Forest Watch website at http: / / earthenginepartners.appspot.com/science-2013-global-forest (accessed date: 16 June 2018) [51], and it was used as the sampling design's template (Table 1). Four categories of canopy cover were created: $10-25 \%,>25-50 \%,>50-75 \%$, and $>75-100 \%$. These canopy covers were used to randomly allocate the field plots. The $10 \%$ coverage value was used to comply with existing forest definitions [52,53]. According to [18], the 30\% canopy cover in the global forest cover dataset corresponded to $10 \%$ cover in southeastern Tanzania. However, in this study the use of the $10 \%$ threshold was justified by the fact that we intended to describe and compare variations of AGB in previously described canopy cover for miombo woodlands across NSR $[15,22,54]$. Moreover, since the miombo canopy cover is highly variable across the region, and we did not test Hansen's data for NSR, we could not assume that the results from Tanzania were valid for this area.

A global positioning system (GPS, GPSMAP 64sx) receiver was used to navigate to the coordinates of the southwestern vertex of the plot. Since plot position errors are common between 3 and $5 \mathrm{~m}$ [55], the coordinates of the center of each plot were recorded. In order to avoid propagating geolocation error, a buffer was applied around the plot center with a radius of $50 \mathrm{~m}$ and enclosed in a $100 \times 100 \mathrm{~m}$ square to conform with the size of the field plot (1 ha). 
In each plot, trees with diameter at breast height $(d b h) \geq 5 \mathrm{~cm}$ ( $d b h$ range from 5 to $83 \mathrm{~cm}$ ) were measured by using a caliper (Haglöf Sweden, precision: $1 \mathrm{~mm}$ ), and identified to the species level.

Table 1. Canopy cover, area per canopy cover, number of plots per canopy cover, number of trees per hectare (trees/ha), diameter at breast height ( $d b h)$ range observed, and mean of $d b h$.

\begin{tabular}{cccccc}
\hline $\begin{array}{c}\text { Canopy } \\
\text { Cover } \mathbf{( \% )}\end{array}$ & area $\left(\mathbf{K m}^{\mathbf{2}}\right)$ & Plots & Trees/ha & $\begin{array}{c}d b h \text { Range } \\
(\mathbf{c m})\end{array}$ & $\begin{array}{c}\text { Mean } d b h \\
(\mathbf{c m})\end{array}$ \\
\hline $10-25$ & 16,702 & 8 & 332 & $5-50$ & 10.63 \\
$25-50$ & 15,208 & 7 & 426 & $5-65$ & 12.64 \\
$50-75$ & 2748 & 5 & 564 & $5-83$ & 12.13 \\
$75-100$ & 85 & 4 & 633 & $5-64$ & 12.22 \\
All & 34,743 & 24 & 1955 & $5-83$ & 11.93 \\
\hline
\end{tabular}

a Forest tree cover by Hansen et al. (2013).

\subsubsection{Remotely Sensed Data}

A previous remote-sensing study carried out in NSR, developed the AGB model using a stepwise regression based on the fusion of $30 \mathrm{~m}$ Landsat 7 enhanced thematic mapper (ETM+) simple ratio (SR) and standard beam $30 \mathrm{~m}$ RADARSAT C-band $(5.7 \mathrm{~cm}$ wavelength) backscatter data with field estimates from fifty $30 \mathrm{~m}$ diameter plots [22]. This study found a significant but moderate relationship between stand estimates and remotely sensed variables $\left(r^{2}=0.55, p<0.0001\right.$ [22]). The study recommended testing finer-spatialresolution optical and radar data in future studies. Table 2 shows the set of satellite images and their characteristics used to predict the AGB in this study. We used the improved optics of 2017 Landsat 8/Operational Land Imager (OLI, USGS 2013) scenes and the Sentinel 2A/MultiSpectral Instrument (MSI) (Table 2). These datasets are both freely available from https: / / earthexplorer.usgs.gov / (accessed on: 11 April 2018). Synthetic aperture radar (SAR) data with finer spatial resolution were also selected for this study, including $201710 \mathrm{~m}$ Sentinel 1B C-band data, which is also freely available (https:/ / search.asf.alaska.edu/\#/, accessed on: 11 April 2018), and the 2016 Phased Array Type L-band (PALSAR) on board the Advanced Land Observing Satellite (ALOS-2) platform. ALOS/PALSAR-2 is available from http:/ / www.eorc.jaxa.jp/ALOS/en/palsar_fnf/fnf_index.htm (accessed on: 13 April 2018). Both radar datasets are available in different polarizations (Table 2). Additionally, the availability of cloud-free and freely available images was the main decision criterion for data selection.

Table 2. Remote-sensing data used for above-ground biomass modelling (NDVI = Normalized Difference Vegetation Index; SAVI = Soil-Adjusted Vegetation Index; SR = simple ratio; VV = verticalvertical; $\mathrm{VH}$ = vertical-horizontal; $\mathrm{HH}$ = horizontal-horizontal; $\mathrm{HV}=$ horizontal-vertical).

\begin{tabular}{|c|c|c|c|c|c|}
\hline $\begin{array}{c}\text { Remote-Sensing } \\
\text { Data }\end{array}$ & Wavelength & $\begin{array}{c}\text { Spatial } \\
\text { Resolution }\end{array}$ & Acquisition Date & Path/Row & Transformations \\
\hline Landsat 8/OLI & $\begin{array}{l}\text { Red (band 4) and } \\
\text { near-infrared } \\
\text { (Band 5) }\end{array}$ & $30 \mathrm{~m}$ & May 2017 & $\begin{array}{l}166 / 68,167 / 68 \\
166 / 69,167 / 69\end{array}$ & $\mathrm{NDVI}_{1}, \mathrm{SAVI}_{1}, \mathrm{SR}_{1}$ \\
\hline Sentinel 2A/MSI & $\begin{array}{l}\text { Red (Band 4) and } \\
\text { near-infrared } \\
(\text { Band } 8)\end{array}$ & $10 \mathrm{~m}$ & April 2017 & $\begin{array}{c}\text { T36LZL, T36LZM, } \\
\text { T36LZM, T36LZN, } \\
\text { T37LBF, T37LBG, } \\
\text { T37LCF, T37LCF, } \\
\text { T37LCH, T37LDG, } \\
\text { T37LDH }\end{array}$ & $\mathrm{NDVI}_{2}, \mathrm{SAVI}_{2}, \mathrm{SR}_{2}$ \\
\hline Sentinel 1B & C-Band $(\sim 5.7 \mathrm{~cm})$ & $10 \mathrm{~m}$ & February 2017 & $\begin{array}{l}155253 / 009606 \\
160043 / 009679 \\
160108 / 009679\end{array}$ & $\begin{array}{c}\text { SAR backscatter: } \\
\text { VV, VH }\end{array}$ \\
\hline
\end{tabular}


Table 2. Cont.

\begin{tabular}{|c|c|c|c|c|c|}
\hline $\begin{array}{c}\text { Remote-Sensing } \\
\text { Data }\end{array}$ & Wavelength & $\begin{array}{c}\text { Spatial } \\
\text { Resolution }\end{array}$ & Acquisition Date & Path/Row & Transformations \\
\hline ALOS/PALSAR-2 & L-Band $(\sim 23.6 \mathrm{~cm})$ & $10 \mathrm{~m}$ & March 2016 & $\begin{array}{c}\text { 11E035, 11E036, } \\
\text { 11E037, 11E038, } \\
\text { 12E035, 12E036, } \\
\text { 12E037, 12E038, } \\
\text { 13E035 }\end{array}$ & $\begin{array}{c}\text { SAR backscatter: } \\
\text { HH, HV }\end{array}$ \\
\hline
\end{tabular}

\subsection{Data Processing}

\subsubsection{Aboveground Biomass from Field Data}

Aboveground biomass (AGB) for individual trees was estimated by using an allometric model developed by [56,57] for global dry tropical forests (Equation (1)). The individual tree AGB was then summed up to obtain biomass at the plot level, and then upscaled to the unit area (hectare).

$$
\mathrm{AGB}=\exp [-2.134+2.530 \times \ln (d b h)]
$$

where AGB is the observed aboveground biomass in $\mathrm{Mg}$ for individual tree $i, d b h$ is the tree diameter at breast height in $\mathrm{cm}$, ln: natural logarithm; -2.134 and 2.530: regression coefficients.

Considering mean's comparison of more than two independent groups, the one-way analysis of variance (ANOVA) statistical test was performed to analyze the mean value of AGB between different categories of canopy cover, namely, 10-25\%, >25-50\%, >50-75\%, and $>75-100 \%$ at $95 \%$ confidence level [58].

\subsubsection{Vegetation Indices from Optical Data}

Before extracting the vegetation indices, optical data were preprocessed to remove imperfections obtained during image acquisition [59] and georeferenced to correct for geographic distortions. These data were used in the form of a spectral reflectance (SR) mosaic based on Landsat 8/OLI and Sentinel 2A/MSI to compute vegetation indices. Geometric and atmospheric corrections were conducted [60] using the atmospheric and topographic correction for satellite imagery (ATCOR) algorithm, and the top of atmosphere (TOA) spectral radiance was converted into TOA reflectance $(\rho)$ by using Equation (2).

$$
\rho=\frac{\pi d^{2}}{\bar{\omega} \times \theta_{\text {solar }}} \phi
$$

where $d$ : Earth-Sun astronomical distance; $\phi$ : spectral radiance at the top of the atmosphere; $\bar{\omega}$ : mean solar exoatmospheric irradiances; and $\theta_{\text {solar }}$ : solar zenith angle in degrees.

To explore the relationship between field and passive optical data, we used three vegetation indices: Normalized Difference Vegetation Index (NDVI; Equation (3) [61]), SoilAdjusted Vegetation Index (SAVI, Equation (4) [62]) and Simple Ratio (SR; Equation (5) [63]). These indices are widely used as surrogates of biomass, leaf area index, and other important plant characteristics $[22,64]$.

$$
\begin{gathered}
\text { NDVI }=\frac{\mathrm{NIR}-\mathrm{RED}}{\mathrm{NIR}+\mathrm{RED}} \\
\mathrm{SAVI}=(1+\mathrm{L}) \frac{\mathrm{NIR}-\mathrm{RED}}{\mathrm{NIR}+\mathrm{RED} \times \mathrm{L}} \\
\mathrm{SR}=\frac{\mathrm{NIR}}{\mathrm{RED}}
\end{gathered}
$$


where NIR: near-infrared satellite portion of electromagnetic spectrum; RED: red portion of electromagnetic spectrum; and L: weighting factor that varies from 0 to 1 [62], for which we used the typical value (0.5).

\subsubsection{Backscatter from SAR Data}

The SAR was corrected for geometric distortions and to remove acquisition errors. The preprocessing of SAR data involved removing the speckled noise, which is the main cause of radiometric distortions that impair the interpretation of radar images [65]. This is multiplicative noise that is proportional to the intensity of the sent signal [66]. The visual effect is a grainy texture that can hinder the interpretation of radar images [65]. SAR data were used in the form of backscatter intensity (BI; Equation (6)), which is the amount of energy scattered by the target towards the sensor in relation to the amount of energy that was emitted by the sensor (microwave pulse [36]). BI is expressed as $\sigma$ (sigma-zero), which is a measure of the backscatter intensity of the radar expressed in decibels $(\mathrm{dB})[55,67]$, as shown in Equation (6).

$$
\sigma=10 \times \log _{10} \mathrm{DN}^{2}-\mathrm{K}
$$

where $\sigma$ : backscatter intensity, DN: digital numbers, brightness value (BV), or radiometric value of image pixels measured in the SAR image (more precisely, the mean pixel value in a group of pixels), K: calibration factor that varies depending on the SAR sensor and the processor system used. For ALOS/PALSAR-2 and Sentinel 1B data, the calibration factor is $-83.0 \mathrm{db}[68]$.

\subsubsection{Extraction of Remotely Sensed Data for Field Plots}

Variables from RS data were extracted from window size $100 \times 100 \mathrm{~m}$ woodland stands. Images with $30 \mathrm{~m}$ of spatial resolution (Landsat) were transformed into $10 \mathrm{~m}$ resolution to allow for the extraction of digital data in the selected window and to harmonize with resolution of the other RS data. All values of the pixels presented normal distribution ( $n=2400$ pixels, Shapiro wilk test $=0.9607$, calculated $p=0.4517$ and $\alpha=0.05)$. For the optical images, mean values of NDVI, SAVI, and SR were extracted, while for bands C (wavelength $\sim 5.7 \mathrm{~cm}$ ) and L (wavelength $\sim 23.6 \mathrm{~cm}$ ), SAR mean BI were extracted [67]. All RS data extracted from the optical and radar images are shown in Appendix A.

\subsubsection{Modelling of Aboveground Biomass}

\section{Model Building}

In this study, a multiple linear regression model [69] was used to explore the relationships between AGB from the field and RS data (Landsat 8/OLI, Sentinel 1B, Sentinel 2A/MSI and ALOS/PALSAR-2; Equation (7)). Stepwise regression was performed in the Minitab ${ }^{\circledR}$ version 18.0 (LLC, Pennsylvania State University, State College, PA, USA) statistical package, and the confidence level was set at $95 \%$. The stepwise process enters each independent variable, evaluates the differences in mean and the correlation to those variables already entered in the process, and eliminates redundant variables [69-71].

$$
\mathrm{AGB}=b_{0}+b_{1} x_{1}+b_{2} x_{2}+\cdots b_{i} x_{i}+\varepsilon
$$

where: AGB: aboveground biomass $\left(\mathrm{Mg} \mathrm{ha}^{-1}\right), x: \mathrm{NDVI}_{1}, \mathrm{SAVI}_{1}, \mathrm{SR}_{1}$ and $\mathrm{NDVI}_{2}, \mathrm{SAVI}_{2}$, $\mathrm{SR}_{2}$ from Landsat 8/OLI and Sentinel 2A/MSI, respectively, and backscatter from SAR $(\mathrm{HH}, \mathrm{HV}, \mathrm{VV}, \mathrm{VH})$; see also Appendix $\mathrm{A} ; b_{0}$ : coefficients of the model; and $\varepsilon$ : random error.

\section{Model Performance Assessment}

To assess model performance, three statistical evaluators were used: coefficient of determination $\left(r^{2}\right.$, Equation (8)), root mean square error (RMSE; Equation (9)) and RMSE \% (Equation (10)) [16,69-72]. In general, a higher $r^{2}$ value and lower RMSE\% value indicate better performance of the model [71]. These statistical measures are widely used in biomass 
modelling to evaluate discrepancies between measured and predicted AGB [73]. To validate the model, these statistics were computed using 10-fold cross-validation [16,71].

$$
\begin{gathered}
R^{2}=\frac{S Q R}{S Q T}=\frac{\sum_{i=1}^{n}\left(y_{0}-y_{p}\right)}{\sum_{i=1}^{n}\left(y_{0}-y_{p}\right)} \\
\mathrm{RMSE}=\sqrt{\frac{\sum_{i=1}^{n}\left(y_{o}-y_{p}\right)^{2}}{n}} \\
\mathrm{RMSE}=\frac{\mathrm{RMSE}}{\overline{y_{0}}}
\end{gathered}
$$

where $n$ : number of plots (24), $y_{o}$ : observed AGB $\left(\mathrm{Mg} \mathrm{ha}^{-1}\right)$ value for plot $i$ and $y_{p}$ : the predicted AGB ( $\left.\mathrm{Mg} \mathrm{ha}^{-1}\right)$ value for plot $i$, RMSE: root mean square error and the mean AGB (Mg ha $\left.{ }^{-1}\right)$ was calculated from the field plots.

To compare the best selected models of AGB, we used the Akaike information criterion (AIC; Equation (11)) and Bayesian information criterion (BIC; Equation (12)) [71]. Both AIC and BIC provide simple and effective methods for selecting and comparing regression models. Models were ranked from the lowest to the highest AIC and BIC scores; the model with the lowest AIC and BIC values was considered to be the best for AGB estimations in NSR [73].

$$
\begin{gathered}
\mathrm{AIC}=n \times \log \frac{S S E}{n}+2 k \\
\mathrm{BIC}=n \times \log \frac{S S E}{n}+\log (n) \times k
\end{gathered}
$$

where $n$ : number of plots (24), SSE: sum squares errors and $k$ : number of parameters $(k=p$ +1 , where $p$ is the number of predictors).

\section{Results}

\subsection{Field Estimations of Aboveground Biomass}

Our results from the stand data indicated that the mean AGB in NSR was $56 \mathrm{Mg}$ $\mathrm{ha}^{-1}$, ranging from 11 to $95 \mathrm{Mg} \mathrm{ha}^{-1}$ (Table 3). Table 3 also shows the corresponding AGB values per tree canopy cover. The ANOVA at the $95 \%$ of confidence interval revealed significant statistical differences among AGB according to canopy cover (F-calculated $=72.8$ $>$ F-critical $=3.02, p<0.05)$.

Table 3. Estimates of aboveground biomass (AGB) by canopy cover in Niassa Special Reserve in 2017. Different superscript letters, i.e., ${ }^{a-d}$, indicate statistical differences of AGB between canopy cover using ANOVA at $95 \%$ confidence level.

\begin{tabular}{cccc}
\hline \multirow{2}{*}{ Canopy Cover (\%) } & \multicolumn{3}{c}{ AGB at Plot Level (Mg ha $\left.{ }^{-1}\right)$} \\
\cline { 2 - 4 } & Range & Mean & Std.dev $^{\text {e }}$ \\
\hline $10-25$ & $11-58$ & $30.0^{\mathrm{a}}$ & 14.0 \\
$25-50$ & $42-80$ & $61.7^{\mathrm{b}}$ & 11.7 \\
$50-75$ & $64-74$ & $67.8^{\mathrm{c}}$ & 4.2 \\
$75-100$ & $75-95$ & $83.0^{\mathrm{d}}$ & 7.5 \\
Average & $11-95$ & 56.0 & 22.6 \\
\hline
\end{tabular}

e Standard deviation.

\subsection{Aboveground Biomass and Remote Sensing Data}

The best correlations between field measurements of biomass and remote-sensing datasets were found with $\mathrm{NDVI}_{1}$ (OLI; $\left.r=0.60 ; p<0.05\right)$, $\mathrm{NDVI}_{2}$ (Sentinel 1B; $r=0.63$; $p<0.05)$ and ALOS/PALSAR $2 \mathrm{BI}(\sigma \mathrm{oHH} ; r=0.63 ; p<0.05$ and $\sigma \mathrm{oHV} ; r=0.63 ; p<0.05)$ (Table 3). The second highest correlation was with $\mathrm{SR}_{2}$ (Sentinel $2 \mathrm{~A} ; r=0.50 ; p<0.05$ ) and backscatter from Sentinel 1B $(\sigma o V H ; r=0.50 ; p<0.05)$. All other variables produced 
$\mathrm{r} \leq 0.50$ relationships with field biomass below 0.50 and were thus removed from further analysis.

\subsection{Aboveground Biomass Models}

The four selected biomass models are shown in Table 4. For Model 1, the RMSE value (17.27 $\mathrm{Mg} \mathrm{ha}^{-1}$ ) was high when compared to that of the other models. The $r^{2}$ value indicates that about $46.6 \%$ of AGB per hectare is explained by the variable $\mathrm{NDVI}_{2}$, and that the remaining $54 \%$ is explained by other variables not introduced in the model. For Models 2 and 3, performance increased with coefficients of determination of $52.08 \%$ and $65.85 \%$, and RMSE values decreased to 16.11 and $13.55 \mathrm{Mg} \mathrm{ha}^{-1}$, respectively. Model 4 performed better than the others with an $r^{2}$ value of $87.5 \%$ for variables $\mathrm{NDVI}_{1}$ from Landsat 8/OLI, $\mathrm{NDVI}_{2}$ from Sentinel 2A/MSI, and $\sigma \mathrm{HV}$ from ALOS/PALSAR-2 (Table 4). The model also had low AIC (123), BIC (51.93) and RMSE \% (11.56 or 20.56\%). Other radar variables ( $\sigma \mathrm{VV}$ and $\sigma \mathrm{VH})$ were not considered to be strong enough to be included in the regression models. As previously indicated, these two variables $(\sigma \mathrm{VV}$ and $\sigma \mathrm{VH})$ have low correlation with AGB with $r^{2}=0.27$ and $r^{2}=0.33$, respectively.

Table 4. Summary of 4 multiple-regression models for prediction of aboveground biomass (AGB) from remotely sensed data in Niassa Special Reserve in 2017. $r^{2}=$ determination coefficient; RMSE = root mean square error; $\mathrm{AIC}=$ Akaike information criterion; and $\mathrm{BIC}=$ Bayesian information criterion .

\begin{tabular}{|c|c|c|c|c|c|c|c|c|c|}
\hline \multirow{3}{*}{ Models } & \multicolumn{8}{|c|}{ Fit Statistics } & \multirow{3}{*}{$\begin{array}{c}\text { RMSE } \\
(\%)\end{array}$} \\
\hline & \multicolumn{4}{|c|}{ Coefficients } & \multirow{2}{*}{$r^{2}$} & \multirow{2}{*}{ AIC } & \multirow{2}{*}{ BIC } & \multirow{2}{*}{ RMSE } & \\
\hline & $\beta_{0}$ & $\beta_{1}$ & $\beta_{2}$ & $\beta_{3}$ & & & & & \\
\hline${ }^{1}$ Model 1 & 20.19 & 156.1 & & & 46.66 & 136 & 58.56 & 17.24 & 30.78 \\
\hline${ }^{2}$ Model 2 & 134.3 & 3.23 & 33.88 & & 52.08 & 138 & 60.34 & 16.11 & 28.76 \\
\hline${ }^{3}$ Model 3 & 92.4 & 110.1 & 4.66 & & 65.85 & 128 & 55.21 & 13.55 & 24.2 \\
\hline${ }^{4}$ Model 4 & 126.5 & 151.4 & 250.1 & 6.63 & 87.5 & 123 & 51.93 & 11.56 & 20.46 \\
\hline
\end{tabular}

\subsection{Mapping Aboveground Biomass}

We mapped the AGB of the study area using Model 4 (Table 4), which demonstrated the effectiveness of using remote-sensing data, especially the fusion of ALOS/PALSAR-2 $\sigma \mathrm{HV}$, and NDVI from Landsat 8/OLI and Sentinel 2 data to estimate AGB. The scatter plots of observed aboveground biomass versus model-estimated (fitted) aboveground biomass for 24 field plots is demonstrated in Figure 2. The mean predicted AGB for the entire NSR was roughly $63 \mathrm{Mg} \mathrm{ha}^{-1}$ with a standard deviation of $20.3 \mathrm{Mg} \mathrm{ha}^{-1}\left(63 \pm 20.3 \mathrm{Mg} \mathrm{ha}^{-1}\right)$, ranging from 0.6 and $200 \mathrm{Mg} \mathrm{ha}^{-1}$, which was slightly higher than the field data estimations (56 Mg ha ${ }^{-1}$, Table 3). The lower end of AGB estimations corresponded to bare soil, agricultural fields, and human settlements or corridors, while the upper end to dense evergreen forests on top of the Mecula and Jao Mountains (the two highest points in the reserve). The open to medium density canopy (25-50\% canopy cover) represents approximately $80 \%$ of the NSR, and the AGB was estimated at $50-100 \mathrm{Mg} \mathrm{ha}^{-1}$. There seems to be an overestimation of the value in the upper end, which was likely due to the saturation of satellite images at a high level of canopy cover (above $80 \mathrm{Mg} \mathrm{ha}^{-1}$ ) as discussed below. The spatial distribution of AGB is shown in Figure 3. 

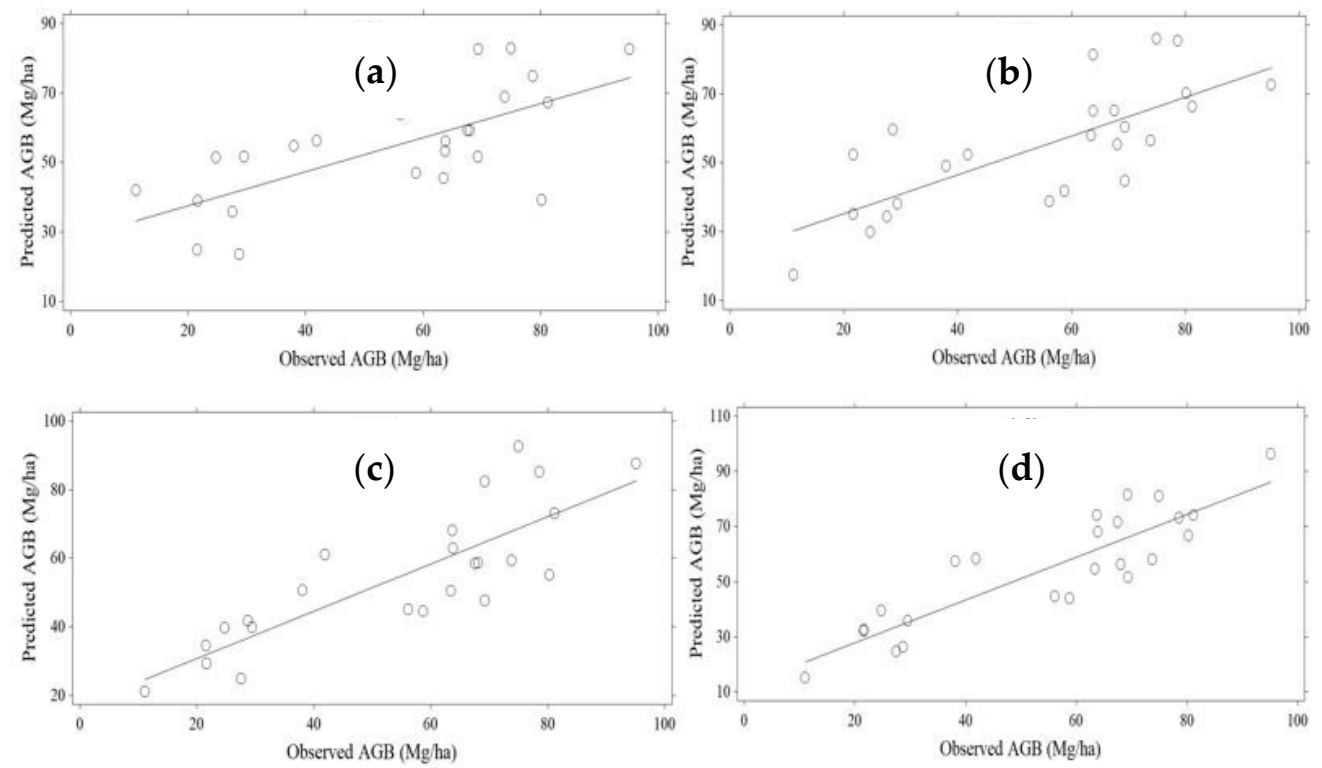

Figure 2. Scatter plots of observed aboveground biomass versus model-estimated (fitted) aboveground biomass values for 24 field plots. (a) Model 1; (b) Model 2; (c) Model 3; and (d) Model 4.

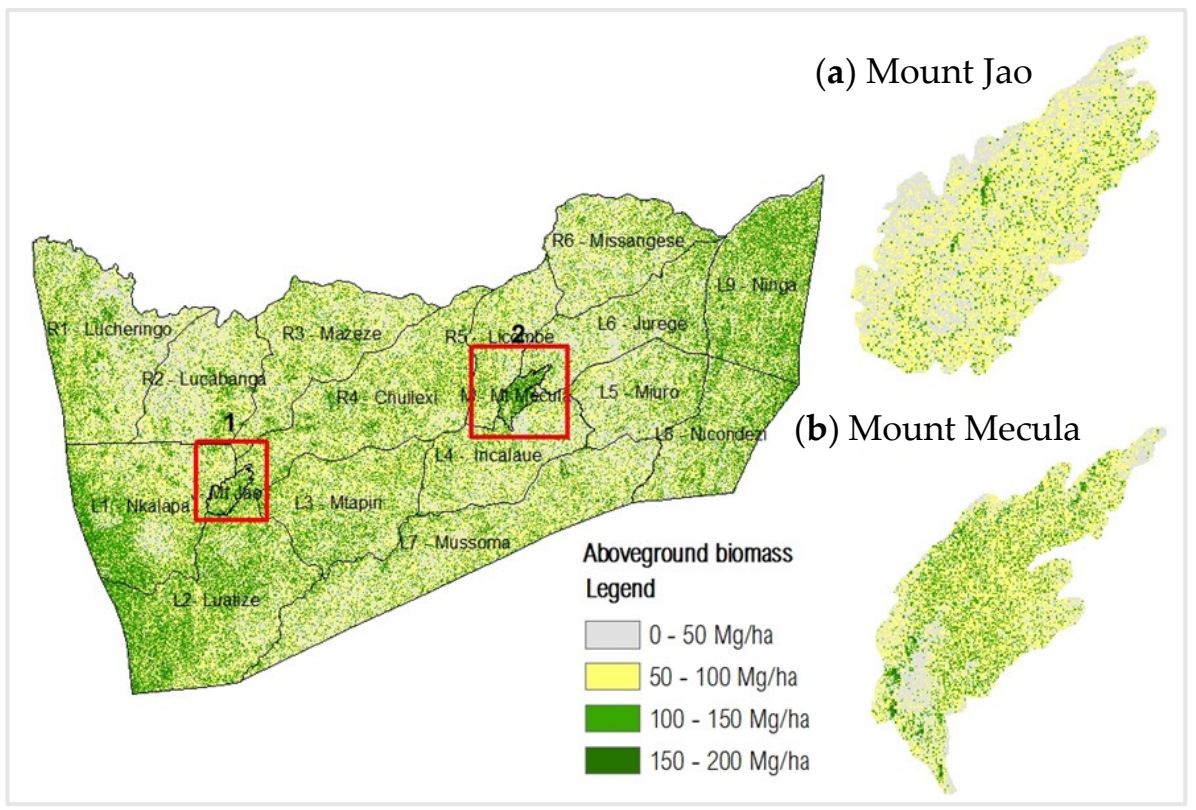

Figure 3. Map of 2017 aboveground biomass in Niassa Special Reserve developed using equation: $\mathrm{AGB}=126.5-151.4 \mathrm{NDVI}_{1}+250.1 \mathrm{NDVI}_{2}+6.63 \sigma \mathrm{oHV}+2.83$. Peak of AGB $\left(200 \mathrm{Mg} \mathrm{ha}^{-1}\right)$ found at (a) Mount Jao and (b) Mount Mecula.

\section{Discussion}

This study represents an update of the 2008 AGB map for NSR [22], and it revealed that L-band, backscatter, and NDVI improved the previous map $\left(r^{2}=0.88\right.$ vs. $\left.r^{2}=0.5\right)$ obtained by [22]. This may have been because, in the current work, field estimations were conducted in larger plots (1 ha plots as opposed to the study by [22]). On the other hand, the predictive regression model explained $87.5 \%$ of variation in AGB data, which corresponds to a $30 \%$ increase in mapping accuracy compared to the 2008 map. This was expected given that the L-band captures signals from stems in addition to the top of the canopy, and saturates at higher values of biomass $\left(80 \mathrm{Mg} \mathrm{ha}^{-1}[23,74]\right)$ than the C-band $\left(50 \mathrm{Mg} \mathrm{ha}^{-1}\right)$ used in the previous study does. In addition, according to [34], ALOS satellite sensors 
have been widely used in the last few decades for the prediction of forest biomass due to their good performance. According to [75], sensors used in isolation, such as AVNIR-2 and ALOS/PALSAR, have reasonable estimates, but an integration of these sensors improves the robustness of the AGB models. Although the results of this study are satisfactory, sampling intensity, and consistent application of sampling probability design and the use of inferential analysis [28,76] would bring more consistent results and allow for applying nonlinear models, so we recommend this type of analysis for future studies.

From the used variables to build the AGB regression model, $\sigma \mathrm{VV}$ and $\sigma \mathrm{VH}$ from Sentinel 1B (C-band $~ 5.7 \mathrm{~cm})$ ) were not selected as predictors of AGB. As previously highlighted, these two variables $(\sigma \mathrm{VV}$ and $\sigma \mathrm{VH})$ had low correlation with field AGB ( $r=0.27$ and $p<0.05$, and $r=0.33 ; p<0.05$, respectively). According to [1], SAR backscatter is a good estimator of AGB, especially when combined with optical images. However, when variables are of a short band wavelength, such as the Sentinel $1 B$ used in this study, they may not correlate well with AGB due to pixel saturation [22,35] at a biomass above $50 \mathrm{Mg}$ $\mathrm{ha}^{-1}$, i.e., at a certain point, as AGB increases, pixel values tend to remain unresponsive [67].

The AGB map revealed that there were variations in biomass distribution across the reserve, which might be associated with patterns of human population density and also different vegetation densities (Table 5). For instance, the Lugenda-Mecula corridor (L4-L8 in Figure 3) corresponds to low AGB (0.6-10 $\left.\mathrm{Mg} \mathrm{ha}^{-1}\right)$, and the same pattern was observed towards the west in the R1, R2, and L1 management areas. All these areas correspond to human settlements or corridors to Tanzania in the north (Ribeiro, unpublished). About $80 \%$ of the reserve is covered by lowland semideciduous miombo (yellow and light green colors in Figure 3), and these corresponded to an average AGB between 75 and $125 \mathrm{Mg} \mathrm{ha}^{-1}$, which is within the range expected for this type of miombo [77].

Table 5. Pearson's correlation between stand estimates of aboveground biomass and remotely sensed data in Niassa Special Reserve.

\begin{tabular}{|c|c|c|c|c|c|c|c|c|c|c|}
\hline \multirow{2}{*}{ Parameters } & \multicolumn{10}{|c|}{ Variables from Remote-Sensing Data } \\
\hline & $\mathrm{NDVI}_{1}$ & $\mathrm{SAVI}_{1}$ & $\mathrm{SR}_{1}$ & $\mathrm{NDVI}_{2}$ & $\mathrm{SAVI}_{2}$ & $\mathrm{SR}_{2}$ & $\sigma \mathrm{HH}$ & $\sigma \mathrm{HV}$ & $\sigma \mathrm{VH}$ & $\sigma \mathbf{V V}$ \\
\hline Pearson's correlation & 0.60 & 0.30 & 0.47 & 0.63 & 0.20 & 0.50 & 0.63 & 0.63 & 0.50 & 0.42 \\
\hline$R$-squared $\left(R^{2}\right)$ & 0.40 & 0.08 & 0.22 & 0.50 & 0.04 & 0.30 & 0.49 & 0.49 & 0.23 & 0.18 \\
\hline
\end{tabular}

The average AGB for the entire NSR of $63 \mathrm{Mg} \mathrm{ha}^{-1}$ was below the estimations from [22] (70 $\left.\mathrm{Mg} \mathrm{ha}^{-1}\right)$, but as discussed above, this estimation represents an improvement on the previous work. Estimations of AGB for the miombo region are very variable depending on factors such as the used method, the sampling effort, and the land cover history $[15,36,37,78,79]$. This makes comparisons among different miombo sites very difficult if not impossible [80]. Considering that the NSR is one of the most pristine areas of miombo in the region, we can assume that the estimates found in this study are an accurate estimation of AGB of dry miombo woodlands. The recent forest reference level report submitted to the UNFCCC refers an average AGB for semideciduous Mozambican miombo (about $70 \%$ of NSR's vegetation) [22] of 62.24 (59.51-64.97) $\mathrm{Mg} \mathrm{ha}^{-1}$ and for the semievergreen forests (corresponding to Mecula and Jao mountains or $0.6 \%$ of NSR [22]) a value of about 99.89 (93.98-105.81) $\mathrm{Mg} \mathrm{ha}^{-1}$ [12]. The peak estimate observed in this study for the Jao and Mecula mountains was $200 \mathrm{Mg} \mathrm{ha}^{-1}$. In agreement with [27], the mountains' moist evergreen forest (290.73 $\mathrm{Mg} \mathrm{ha}^{-1}$ ) stores up to four times more carbon than that of the miombo woodlands of southern Africa lowlands. The AGB in dry miombo woodland is usually low, about $55 \mathrm{Mg} \mathrm{ha}^{-1}$ (ranging between 21 and $84 \mathrm{Mg} \mathrm{ha}^{-1}$ ), while for wet miombo woodland it is about $90 \mathrm{Mg} \mathrm{ha}^{-1}$ (ranging between 44 and $144 \mathrm{Mg} \mathrm{ha}^{-1}$ ) [79].

NSR should be considered to be a top priority in the context of ongoing financing mechanisms to mitigate climate change, such as the Payment for Ecosystem Services (PES) and the REDD+. In this context, it is important to consider the spatial distribution of AGB and carbon stocks, which indicate the areas where REDD+ activities should be concentrated. 
It is also important to take into consideration the variety of factors involved in determining carbon balance in NSR, such as human activities (agriculture, honey gathering, among others) and anthropogenic fires [81]. These continue to coexist in NSR in the long run as a result of increasing human population both inside and outside the area [38,41,42]. Consequently, it is important to engage local communities in conservation action and decision making.

\section{Conclusions}

The main objectives of this study were to estimate AGB, and develop an AGB model using passive and active data. Three main conclusions can be drawn from this study. First, the mean AGB estimated from the field data was $56 \mathrm{Mg} \mathrm{ha}^{-1}$ (ranging from 11 to $\left.95 \mathrm{Mg} \mathrm{ha}^{-1}\right)$. These estimations are within the range that was reported in the existing literature for this type of forest. Second, the study showed that vegetation indices derived from Landsat/OLI $\left(\mathrm{NDVI}_{1}\right)$ and Sentinel $2 \mathrm{~A} / \mathrm{MSI}\left(\mathrm{NDVI}_{2}\right)$, and the backscatter of the $\sigma \mathrm{OHV}$ polarization from ALOS/PALSAR-2 are good predictors of AGB. The developed biomass model presented the best fit, so auxiliary remotely sensed data may help in improving the precision of AGB estimates. However, we recommend that our model could be improved with more sampling plots for future studies. Third, the estimate of AGB may be a crucial source for MRV REDD+ initiatives not only in the study area, but also in other areas with similar environmental conditions; therefore, further analysis is necessary in this regard. We recommended to engage the NSR in the Warsaw REDD+ Framework for better management of forest resources and income generation for local communities, reducing deforestation and forest degradation because miombo woodland has huge potential to provide financial resources through payment for ecosystem services under the REDD+ mechanism.

Author Contributions: O.A.M.: formal analysis, investigation, writing—original draft; N.S.R.: conceptualization, methodology, writing — original draft, supervision, project administration, fund acquisition; A.I.R.: conceptualization, fund acquisition, writing-review and editing; A.C.: methodology, investigation, writing - review and editing; R.B.: writing - review and editing; C.B.: methodology; R.W.-A.: writing-review and editing. All authors have read and agreed to the published version of the manuscript.

Funding: This study was supported by the Italian Cooperation through the "Fundo de Investigação Multisectorial e Aplicada em Moçambique (FIAM)", the National Research Fund (FNI) in Mozambique, and Fundação para a Ciência e Tecnologia through research unit UIDB/00239/2020 (CEF), Portugal.

Institutional Review Board Statement: Not applicable.

Informed Consent Statement: Not applicable.

Data Availability Statement: All data generated or analyzed during this study are included in this published article.

Acknowledgments: The authors would like to recognize the valuable contribution of the many individuals and institutions. We thank the National Administration of Conservation Areas (ANAC) in Mozambique and the Wildlife Conservation Society (WCS) for their support over the years of work in Niassa Special Reserve and the many field assistants throughout the years. We also thank funding agency Agenzia Italiana per la Cooperazion allo Sviluppo, Italia through grant number 5.1.2.3.

Conflicts of Interest: The authors declare no conflict of interest. 


\section{Appendix A}

Table A1. Remote-sensing data extracted from each field plot.

\begin{tabular}{|c|c|c|c|c|c|c|c|c|c|c|c|c|}
\hline \multirow{3}{*}{$\begin{array}{c}\text { Plot } 1 \\
\text { ha }\end{array}$} & \multirow{3}{*}{$\begin{array}{l}\text { Plot } \\
\text { Cod }\end{array}$} & \multirow{3}{*}{$\begin{array}{l}\text { Biomass } \\
\text { (Mg/ha) }\end{array}$} & \multicolumn{10}{|c|}{ Variables from Remote Sensing Data } \\
\hline & & & \multicolumn{3}{|c|}{ Landsat 8/OLI } & \multicolumn{3}{|c|}{ Sentinel 2/MSI } & \multicolumn{2}{|c|}{ Alos/Palsar 2} & \multicolumn{2}{|c|}{ Sentinel 1B } \\
\hline & & & $\mathrm{NDVI}_{1}$ & SAVI $_{1}$ & $\mathrm{SR}_{1}$ & $\mathrm{NDVI}_{2}$ & $\mathrm{SAVI}_{2}$ & $\mathrm{SR}_{2}$ & боHН & бoHV & бoVH & ooVV \\
\hline 1 & AS & 81.3 & 0.35 & 0.33 & 5.0 & 0.30 & 0.31 & 3.5 & -7.64 & -11.2 & -26.16 & -27.0 \\
\hline 2 & $\mathrm{AP}$ & 24.8 & 0.20 & 0.30 & 3.0 & 0.20 & 0.30 & 2.2 & -13.1 & -16.1 & -27.62 & -28.9 \\
\hline 3 & DR & 21.7 & 0.15 & 0.10 & 4.0 & 0.12 & 0.11 & 3.2 & -7.04 & -15.3 & -23.29 & -21.4 \\
\hline 4 & $\mathrm{CP}$ & 27.6 & 0.12 & 0.40 & 3.5 & 0.10 & 0.40 & 2.3 & -10.6 & -16.9 & -28.67 & -27.0 \\
\hline 5 & CR & 21.7 & 0.35 & 0.30 & 2.0 & 0.10 & 0.30 & 2.0 & -13.6 & -14.3 & -28.06 & -28.1 \\
\hline 6 & CS & 69.4 & 0.20 & 0.32 & 3.8 & 0.20 & 0.30 & 3.4 & -10.6 & -14.3 & -24.94 & -25.7 \\
\hline 7 & ER & 69.4 & 0.45 & 0.37 & 5.0 & 0.40 & 0.40 & 4.5 & -8.99 & -11.6 & -23.62 & -21.4 \\
\hline 8 & $\mathrm{EP}$ & 58.8 & 0.20 & 0.15 & 4.0 & 0.17 & 0.13 & 4.0 & -11.5 & -14.3 & -23.27 & -22.3 \\
\hline 9 & $\mathrm{CQ}$ & 63.5 & 0.18 & 0.15 & 2.8 & 0.16 & 0.11 & 2.0 & -8.32 & -12.8 & -25.65 & -28.1 \\
\hline 10 & $\mathrm{ES}$ & 63.8 & 0.25 & 0.20 & 6.0 & 0.21 & 0.18 & 5.5 & -4.28 & -10.2 & -22.43 & -18.7 \\
\hline 11 & $\mathrm{DP}$ & 78.7 & 0.50 & 0.32 & 7.5 & 0.35 & 0.30 & 5.0 & -3.30 & -9.89 & -22.13 & -18.4 \\
\hline 12 & $\mathrm{FP}$ & 41.9 & 0.30 & 0.24 & 4.5 & 0.23 & 0.20 & 4.0 & -10.8 & -12.2 & -22.86 & -19.3 \\
\hline 13 & FR & 95.2 & 0.40 & 0.30 & 4.0 & 0.40 & 0.28 & 3.3 & -6.48 & -10.5 & -25.00 & -23.4 \\
\hline 14 & $\mathrm{FQ}$ & 73.9 & 0.33 & 0.27 & 3.6 & 0.31 & 0.25 & 3.1 & -6.75 & -14.5 & -24.87 & -19.0 \\
\hline 15 & FS & 56.2 & 0.27 & 0.20 & 3.0 & 0.28 & 0.15 & 3.0 & -9.47 & -16.8 & -22.60 & -20.4 \\
\hline 16 & AR & 67.6 & 0.20 & 0.18 & 2.5 & 0.25 & 0.15 & 2.4 & -5.56 & -13.2 & -23.68 & -20.8 \\
\hline 17 & $\mathrm{AQ}$ & 11.1 & 0.15 & 0.12 & 2.0 & 0.14 & 0.10 & 1.2 & -13.8 & -18.7 & -26.14 & -24.5 \\
\hline 18 & $\mathrm{BP}$ & 80.3 & 0.12 & 0.10 & 2.0 & 0.12 & 0.08 & 1.8 & -6.90 & -10.8 & -25.73 & -25.4 \\
\hline 19 & DQ & 63.9 & 0.25 & 0.21 & 3.8 & 0.23 & 0.20 & 3.5 & -7.33 & -11.8 & -23.88 & -22.3 \\
\hline 20 & BS & 38.1 & 0.20 & 0.18 & 3.0 & 0.22 & 0.14 & 2.5 & -9.37 & -14.2 & -25.46 & -27.0 \\
\hline 21 & $\mathrm{BQ}$ & 28.7 & 0.20 & 0.15 & 2.5 & 0.10 & 0.15 & 2.0 & -9.47 & -11.4 & -26.00 & -28.4 \\
\hline 22 & $\mathrm{BR}$ & 29.5 & 0.23 & 0.20 & 3.5 & 0.20 & 0.20 & 3.0 & -10.6 & -16.0 & -25.77 & -24.4 \\
\hline 23 & EQ & 68.1 & 0.30 & 0.26 & 4.0 & 0.25 & 0.23 & 4.0 & -8.66 & -13.2 & -23.48 & -21.8 \\
\hline 24 & $\widehat{D S}$ & 75.0 & 0.76 & 0.40 & 6.5 & 0.40 & 0.35 & 6.0 & -3.73 & -9.42 & -22.00 & -16.8 \\
\hline
\end{tabular}

\section{References}

1. Eastman, J.R.; Idrisi, A. Guide to GIS and Image Processing; Clark Laboratory Clark University: Worcester, MA, USA, 2006.

2. Fehrmann, L.; Kleinn, C. Nearest Neighbour Approach for Estimation of single-Tree Biomass. In Proceedings of the Seventh Annual Forest Inventory and Analysis Symposium; U.S. Department of Agriculture, Forest Service: Washington, DC, USA, 2005.

3. PCC. Good Practice Guidance for Land Use, Land-Use Change and forestry. National Inventory Reports. 2003. Available online: https:/ / www.ipcc-nggip.iges.or.jp/public/gpglulucf/gpglulucf_files/GPG_LULUCF_FULL.pdf (accessed on 10 December 2021).

4. World Wide Fund for Nature (WWF). Miombo Eco-region Report “Home of the Zambezi”. In Conservation Strategy: 2011-2020; World Wide Fund for Nature (WWF): Harare, Zimbabwe, 2012.

5. Dziba, L.; Ramoelo, A.; Ryan, C.; Harrison, S.; Pritchard, R.; Tripathi, H.; Sitas, N.; Selomane, O.; Engel, B.F.; Pereira, L.; et al. Scenarios for Just and Sustainable Futures in the Miombo Woodlands. In Miombo Woodlands in a Changing Environment: Securing the Resilience and Sustainability of People and Woodlands; Ribeiro, N., Katerere, Y., Chirwa, P.W., Grundy, I.M., Eds.; Springer Nature: Cham, Switzerland, 2020; pp. 191-234.

6. Campbell, B.M.; Cunliffe, R.N.; Gambiza, J. Vegetation structure and small-scale pattern in Miombo woodland, Marondera. Bothalia 1995, 25, a721. [CrossRef]

7. Chidumayo, E.N. Estimating tree biomass and changes in root biomass following clear-cutting of Brachystegia-Julbernardia (Miombo) woodland in central Zambia. Environ. Conserv. 2013, 41, 54-63. [CrossRef]

8. Ryan, C.M.; Pritchard, R.; McNicol, I.; Owen, M.; Fisher, J.A.; Lehmann, C. Ecosystem services from Southern African woodlands and their future under global change. Philos. Trans. R. Soc. B Biol. Sci. 2016, 371, 20150312. [CrossRef] [PubMed]

9. Community (GIZ/SADC). Field Inventory Results: Transboundary Test Area Malawi-Zambia. In Consortium GAF AG and DFS Deutsche Forstservice GmbH; Department of Forestry: Lilongwe, Malawi; Kalomo, Zambia, 2014.

10. FAO. The State of Food Insecurity in the World. In Addressing Food and Insecurity in Protracted Crises; FAO: Rome, Italy, 2010.

11. Skutsch, M.M.; McCall, M.K. The role of community forest management in REDD+. Unasylva 2012, 63, 51-56.

12. MITADER. Inventário Florestal Nacional; MITADER: Maputo, Mozambique, 2018.

13. Centro de Estudos de Agricultura e Gestão de Recursos Naturais (CEAGRE)/Winrock. Identificação e análise dos agentes e causas directas e indirectas de desmatamento e degradação florestal em Moçambique. In Final Report; UEM: Maputo, Mozambique, 2016.

14. Herold, M.; Skutsch, M. Monitoring, reporting and verification for national REDD + programmes: Two proposals. Res. Lett. 2011, 6, 014002. [CrossRef]

15. Ribeiro, N.S.; Matos, C.N.; Moura, I.; Washington-Allen, R.A.; Ribeiro, A.I. Monitoring vegetation dynamics and carbon stock density in miombo woodlands. Carbon Balance Manag. 2013, 8, 11. [CrossRef] 
16. Hansen, E.H.; Gobakken, T.; Bollandsås, Z.; Næsset, E. Modeling aboveground biomass in dense tropical submontane rainforest using airborne laser scanner data. Remote Sens. 2015, 7, 788-807. [CrossRef]

17. IPCC (Intergoveramental Panel on Climate Change). Good Practice Guidance for Land Use, Land-Use Change and forestry. In National Inventory Reports; 2003. Available online: https://www.ipcc-nggip.iges.or.jp/public/gpglulucf/gpglulucf.html (accessed on 10 December 2021).

18. Næsset, E.; Ørka, H.O.; Solberg, S.; Bollandsås, O.M.; Hansen, E.H.; Mauya, E.; Zahabu, E.; Malimbwi, R.; Chamuya, N.; Olsson, $\mathrm{H}$; ; et al. Mapping and estimating forest area and aboveground biomass in miombo woodlands in Tanzania using data from airborne laser scanning, TanDEM-X, RapidEye, and global forest maps as auxiliary information: A comparison of estimated precision. Remote Sens. Environ. 2016, 175, 282-306. [CrossRef]

19. Sitoe, A.; Guedes, B.S.; Nhantumbo, I. Linha de referência, Monitoria, Relatório e Verificação para REDD+ em Moçambique. In Relatório do Pais; IIED: Londres, UK, 2013.

20. Houghton, R.A.; Hall, F.G.; Goetz, S.J. The importance of biomass in the global carbon cycle. J. Geophys. Res. Biogeosci. 2009, 114 [CrossRef]

21. Tchaúque, F.J. Biomassa florestal acima do solo na região do Corredor da Beira. In Tese de Licenciatura em Engenharia Florestal; Faculdade de Agronomia e Engenharia Florestal, Universidade Eduardo Mondlane: Maputo, Moçambique, 2004.

22. Ribeiro, N.S.; Saatchi, S.S.; Shugart, H.H.; Washington-Allen, R. Aboveground biomass and leaf area index (LAI) mapping for niassa reserve, Northern Mozambique. J. Geophys. Res. Biogeosci. 2008, 113. [CrossRef]

23. Saatchi, S.S.; Harris, N.; Brown, S.; Lefsky, M.; Mitchard, E.T.A.; Salas, W.; Zutta, B.R.; Buermann, W.; Lewis, S.L.; Hagen, S.; et al. Benchmark map of forest carbon stocks in tropical regions across three continents. Proc. Nat. Acad. Sci. USA 2011, 108, 9899-9904. [CrossRef] [PubMed]

24. Mate, R.; Johansson, T.; Sitoe, A. Biomass equations for tropical forest tree species in Mozambique. Forests $2014,5,535-555$. [CrossRef]

25. Magalhães, T.M. Live above- and belowground biomass of a Mozambican evergreen forest: A comparison of estimates based on regression equations and biomass expansion factors. For. Ecosyst. 2015, 2, 28. [CrossRef]

26. Guedes, B.S.; Sitoe, A.A.; Olsson, B. Allometric models for managing lowland miombo woodlands of the Beira corridor in Mozambique. Glob. Ecol. Conserv. 2018, 13, e00374. [CrossRef]

27. Lisboa, S.N.; Guedes, B.S.; Ribeiro, N.; Sitoe, A. Biomass allometric equation and expansion factor for a mountain moist evergreen forest in Mozambique. Carbon Balance Manag. 2018, 13, 23. [CrossRef]

28. McRoberts, R.; Næsset, E.; Gobakken, T. Estimation for inaccessible and non-sampled forest areas using model-based inference and remotely sensed auxiliary information. Remote Sens. Environ. 2014, 154, 226-233. [CrossRef]

29. Esteban, J.; McRoberts, R.E.; Fernández, A.; Tomé, J.L.; Marchamalo, M. A model-based volume estimator that accounts for both land cover misclassification and model prediction uncertainty. Remote Sens. 2020, 12, 3360. [CrossRef]

30. Mitchard, E.T.A.; Saatchi, S.S.; Lewis, S.L.; Feldpausch, T.R.; Woodhouse, I.H.; Sonké, B.; Meir, P. Measuring biomass changes due to woody encroachment and deforestation/degradation in a forest-savanna boundary region of central Africa using multi-temporal L-band radar backscatter. Remote Sens. Environ. 2011, 115, 2861-2873. [CrossRef]

31. Baccini, A.; Goetz, S.J.; Walker, W.S.; Laporte, N.T.; Sun, M.; Sulla-Menashe, D.; Hackler, J.; Beck, P.S.; Dubayah, R.; Friedl, M.A.; et al. Estimated carbon dioxide emissions from tropical deforestation improved by carbon-density maps. Nat. Clim. Chang. 2012, 2, 182-185. [CrossRef]

32. Harris, N.L.; Brown, S.; Hagen, S.C.; Saatchi, S.S.; Petrova, S. Baseline map of carbon emissions from deforestation in tropical regions. Science 2012, 336, 1573-1575. [CrossRef]

33. Vibrans, A.C.; McRoberts, R.E.; Moser, P.; Nicoletti, A.L. Using satellite image-based maps and ground inventory data to estimate the area of the remaining Atlantic forest in the Brazilian state of Santa Catarina. Remote Sens. Environ. 2012, 130, 87-95. [CrossRef]

34. Watzlawick, L.F. Estimativa de Biomassa e Carbono em Floresta Ombrófila Mista e Plantações Florestais a Partir de Dados de Imagens do Satélite Ikonos II; UFPR: Curitiba, PR, Brasil, 2009.

35. Urbazaev, M.; Thiel, C.; Cremer, F.; Dubayah, R.; Migliavacca, M.; Reichstein, M.; Schmullius, M. Estimation of forest aboveground biomass and uncertainties by integration of field measurements, airborne LiDAR, and SAR and optical satellite data in Mexico. Carbon Balance Manag. 2018, 13, 5. [CrossRef]

36. Ryan, C.; Williams, M.; Grace, J. Above- and Belowground Carbon Stocks in a Miombo Woodland Landscape of Mozambique. Biotropica 2012, 43, 423-432. [CrossRef]

37. Carreiras, J.M.B.; Melo, J.B.; Vasconcelos, M.J. Estimating the above-ground biomass in Miombo savanna woodlands (Mozambique, East Africa) using L-band synthetic aperture radar data. Remote Sens. 2013, 5, 1524-1548. [CrossRef]

38. Allan, J.R.; Grossmann, F.; Craig, R.; Nelson, A.; Maina, J.; Flower, K.; Bampton, J.; Deffontaines, J.B.; Miguel, C.; Araquechande, B.; et al. Patterns of forest loss in one of Africa's last remaining wilderness areas: Niassa National Reserve (northern Mozambique). Parks 2017, 23, 39-50. [CrossRef]

39. MITADER (Ministério da Terra, Ambiente e Desenvolvimento Rural). Estratégia e Plano de Acção para a Conservação da Diversidade Biológica em Moçambique; MITADER: Maputo, Mozambique, 2005.

40. Cunliffe, R.; Mandondo, A.; Games, I.; Ngarivhume, J.; Doré, D. Reconciling conservation goals with agriculturally based livelihoods. In A Proposal for Future Development of the Niassa National Reserve and Surrounding Areas; Imperial Tobacco Project: Harare, Zimbabwe, 2009. 
41. Ribeiro, N.S.; Cangela, A.; Chauque, A.A.; Bandeira, R.R. Characterisation of spatial and temporal distribution of the fire regime in Niassa National Reserve, northern Mozambique. Int. J. Wildland Fire 2017, 26, 1021-1029. [CrossRef]

42. SGDRN (Sociedade para a Gestão e Desenvolvimento da Reserva do Niassa). Plano de Maneio da Reserva Nacional de Niassa 2007-2012; SGDRN (Sociedade para a Gestão e Desenvolvimento da Reserva do Niassa): Maputo, Mozambique, 2007.

43. Timberlake, J. Botanical Survey of the Niassa Reserve, Mozambique. In Prepared for Sociedade para a Gestão e Desenvolvimento da Reserva do Niassa Moçambique; 2004. Available online: http://biodiversityfoundation.org/documents/BFA\%20No.12_Niassa\%20 Botany.pdf (accessed on 10 December 2021).

44. Booth, V.R.; Dunham, K.M. Elephant poaching in Niassa Reserve, Mozambique: Population impact revealed by combined survey trends for live elephants and carcasses. Oryx 2016, 50, 94-103. [CrossRef]

45. Marzoli, A. Avaliação Integrada das Florestas em Moçambique (AIFM): Inventário Florestal Nacional; MINAG/DNTF: Maputo, Mozambique, 2007.

46. Craig, G.C. Aerial Survey of Wildlife in the Niassa Reserve and Adjacent Areas; Sociedade para a Gestão e Desenvolvimento da Reserva do Niassa: Maputo, Mozambique, 2009.

47. Available online: https://mozambique.wcs.org (accessed on 11 October 2020).

48. Sociedade de Gestão da Reserva Nacional de Niassa (SGDRN). Bolentim Informativo da Reserva Nacional de Niassa-Janeiro; Lugenda: Maputo, Mozambique, 2010.

49. INE (Instituto Nacional de Estatistica). Resultados Preliminares, Censo 2017 e Definitivos de 2007 e 1997. 2018. Available online: http:/ / www.ine.gov.mz. (accessed on 18 November 2018).

50. Sanquetta, C.R.; Watzlawick, L.F.; Corte, A.P.D.; Fernandes, L.A.; Siqueira, J.D. Inventários Florestais: Planejamento e Execução UFPR-Setor de Ciências Agrárias, Departamento de Ciências Florestais-DECIF: Curitiba, Brazil, 2009.

51. Hansen, M.C.; Potapov, P.V.; Moore, R.; Hancher, M.; Turubanova, S.A.; Tyukavina, A. High-resolution global maps of 21st-century forest cover change. Science 2013, 342, 850-853. [CrossRef]

52. FAO. State of the Worlds Forest; FAO: Rome, Italy, 2003.

53. Falcão, M.P.; Noa, M. Definição de Florestas, Desmatamento e Degradação Florestal no âmbito do REDD+; Maputo, Mozambique, 2016. Available online: https:/ / www.biofund.org.mz/wp-content/uploads/2018/06/1528267239-Relatorio\%20definicao\%20de\%20 floresta\%20V5_19.10.2016.pdf (accessed on 10 December 2021).

54. Sitoe, A.; Tchaúque, F. Medição da Biomassa Lenhosa Utilizando Informação do Inventario Florestal; Direcção Nacional de Terras e Florestas, Unidade de Inventario Florestal: Maputo, Mozambique, 2007.

55. Kasischke, E.S.; Melack, J.M.; Dobson, C.M. The use of imaging radars for ecological applications-A review. Remote Sens. Environ. 1997, 59, 141-156. [CrossRef]

56. Brown, S.; Gillespie, A.J.R.; Lugo, A.E. Biomass estimation methods for tropical forests with applications to forest inventory data For. Sci. 1989, 35, 881-902.

57. IPCC (Intergoveramental Panel on Climate Change). Climate Change 2014: Synthesis Report. In Contribution of Working Groups I, II and III to the Fifth Assessment Report of the Intergovernmental Panel on Climate Change; Pachauri, R.K., Meyer, L.A., Eds.; IPCC: Geneva, Switzerland, 2014; p. 151

58. Friedman, J.H. Stochastic gradient boosting. Comput. Stat. Data Anal. 2002, 38, 367-378. [CrossRef]

59. Colwell, R.N. Manual of Remote Sensing, 2nd ed.; American Society of Photogrammetry: Falls Church, VA, USA, 1983 ; Volume 1.

60. Markham, B.; Barsi, J.; Kvaran, G.; Ong, L.; Kaita, E.; Biggar, S.; Czapla-Meyers, J.; Mishra, N.; Helder, D. Landsat-8 Operational Land Imager radiometric calibration and stability. Remote Sens. 2014, 6, 12275-12308. [CrossRef]

61. Rouse, J.W.; Haas, R.H.; Schell, J.A.; Deering, D.W. Monitoring Vegetation Systems in the Great Plains with ERTS. In Proceedings of the Third Earth Resources Technology Satellite-1 Symposium, Goddard Space Flight Center, Washington, DC, USA, 10-14 December 1973; Freden, S.C., Mercanti, E.P., Becker, M.A., Eds.; Scientific and Technical Information Office, National Aeronautics and Space Administration (NASA): Washington, DC, USA, 1974; Volume 351, pp. 3010-3017.

62. Huete, A.R. A soil-adjusted vegetation index (SAVI). Remote Sens. Environ. 1988, 25, 259-309. [CrossRef]

63. Birth, G.S.; McVey, G. Measuring the color of growing turf with a reflectance spectrophotometer 1. Agron. J. 1968, 60, 640-643. [CrossRef]

64. Viganó, H.A.; Borges, E.F.; Franca-Rocha, W.J.S. Análise do Desempenho dos Índices de Vegetação NDVI e SAVI a Partir de Imagens Aster. In Simpósio Brasileiro de Sensoriamento Remoto; Anais: Curitiba, Brazil, 2011.

65. JAXA. The 2nd ALOS Research Announcement: Calibration and Validation, Utilization Research, and Scientific Research; Earth Observation Research Center, Japan Aerospace Exploration Agency, Japan. 2006. Available online: http://www.eorc.JAXA.jp/ ALOS/en/ra/ra2_guide.html (accessed on 13 April 2018).

66. Shimada, M.; Isoguchi, O.; Tadono, T.; Isono, K. "PALSAR Radiometric and Geometric Calibration. IEEE Trans. Geosci. Remote Sens. 2009, 47, 3915-3932. [CrossRef]

67. JAXA. ALOS User Handbook; Earth Observation Research Center, Japan Aerospace Exploration Agency. Japan. 2007. Available online: http:/ / www.eorc.JAXA.jp/ALOS/en/doc/handbk.html (accessed on 13 April 2018).

68. JAXA. Press Release. Advanced Land Observing Satellite. ALOS 2. 2014. Available online: https://global.jaxa.jp/press/alos2/ (accessed on 10 December 2021).

69. Kennedy, P. A Guide to Econometrics. 2008. Available online: http://masonlec.org/site/rte_uploads/files/Econometrics\%20 Book\%20-\%20Intro,\%20Ch\%201\%20and\%202.pdf (accessed on 10 December 2021). 
70. Zanette, V.H. Equações Alométricas de Biomassa Aérea Mista no Paraná. Ph.D. Thesis, Universidade Federal do Parana, Curitiba, Brazil, 2017.

71. Li, Y.; Li, M.; Li, C.; Liu, Z. Forest aboveground biomass estimation using Landsat 8 and Sentinel-1A data with machine learning algorithms. Sci. Rep. 2020, 10, 9952. [CrossRef]

72. Machado, S.; Conceição, M.B.; Figueiredo, D.J. Modelagem do volume individual para diferentes idades e regimes de desbaste em plantações de Pinus oocarpa. RECEN-Rev. Ciênc. Exatas Nat. 2002, 4, 185-197.

73. Pham, T.D.; Yoshino, K.; Bui, D.T. Biomass estimation of Sonneratia caseolaris (1.) Engler at a coastal area of Hai Phong city (Vietnam) using ALOS-2 PALSAR imagery and GIS-based multi-layer perceptron neural network. GISci. Remote Sens. 2016, 54, 329-353. [CrossRef]

74. Ferraz, A.S.; Soares, V.P.; Soares, C.P.; Ribeiro, C.A.; Gleriani, J.M. Uso de imagens do satélite IKONOS II para estimar biomassa aérea de um fragmento de floresta estacional semidecidual. In Proceedings of the Anais XVI Simpósio Brasileiro de Sensoriamento Remoto-SBSR, Foz do Iguaçu, PR, Brasil, 13-18 April 2013; INPE: São José dos Campos, Brasil, 2013.

75. Halperin, J.; LeMay, V.; Chidumayo, E.; Verchot, L.; Marshall, P. Model-based estimation of above-ground biomass in the miombo ecoregion of Zambia. For. Ecosyst. 2016, 3, 14. [CrossRef]

76. McRoberts, R.E. A model-based approach to estimating forest area. Remote Sens. Environ. 2006, 103, 56-66. [CrossRef]

77. Mugasha, A.G.; Chamshama, S.A.O. Tree biomass and volume estimation for Miombo woodlands at Kitulangalo, Morogoro, Tanzania, in Indicators and Tools for Restoration and Sustainable Management of Forests in East Africa, I-TOO Working. 2002. Available online: https:/ / www.tandfonline.com/doi/abs/10.1080/20702620.2004.10431761 (accessed on 10 December 2021).

78. Guy, P.R. Changes in the biomass and productivity of woodlands in the Sengwa. Wildlife Research Area, Zimbabwe. J. Appl. Ecol. 1981, 18, 507-519. [CrossRef]

79. Desanker, P.V.; Frost, P.G.H.; Justice, C.O.; Scholes, R.J. The Miombo Network: Framework for a Terrestrial Transect Study of Land-Use and Land-Cover Change in the Miombo Ecosystems of Central Africa. In IGBP Report 41; The International Geosphere-Biosphere Programme (IGBP): Stockholm, Sweden, 1997.

80. Salimon, C.I.; Putz, F.E.; Menezes-filho, L.; Anderson, A.; Silveira, M.; Brown, F.I.; Oliveira, L.C. Estimating state-wide biomass carbon stocks for a REDD plan in Acre, Brazil. For. Ecol. Manag. 2011, 262, 555-560. [CrossRef]

81. Ribeiro, N.S.; Armstrong, H.A.; Fischer, F.; Kim, Y.S.; Shugart, H.H.; Ribeiro-Barros, A.I.; Chauque, A.; Tear, T.; Washington-Allen, R.; Bandeira, R.R. Prediction of forest parameters and carbon accounting under different fire regimes in Miombo woodlands, Niassa Special Reserve, Northern Mozambique. For. Policy Econ. 2021, 133, 102625. [CrossRef] 